\begin{tabular}{|c|c|c|c|c|}
\hline \multicolumn{5}{|c|}{ НАУЧНО-ТЕХНИЧЕСКИЙ ВЕСТНИК ИНФОРМАЦИОННЫХ ТЕХНОЛОГИЙ, МЕХАНИКИ И ОПТИКИ } \\
\hline 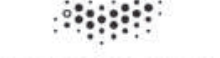 & $\begin{array}{ll}\text { июль-август } 2018 & \text { Том } 18 \text { № } 4 \\
\text { SCIENTIFIC AND TECHNICAL JOURNAL } 0\end{array}$ & $\begin{array}{l}\text { ISSN 2226-1494 } \\
\text { NFORMATION TEC }\end{array}$ & $\begin{array}{l}\text { http://ntv.ifmo.rul } \\
\text { IECHANICS AND OPTICS }\end{array}$ & 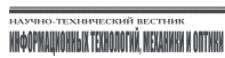 \\
\hline УНИВЕРСИТЕТ ИТМО & July-August 2018 & ISSN 2226-1494 & http://ntv.ifmo.ru/en & \\
\hline
\end{tabular}

\title{
A MULTI-AGENT SYSTEM FOR MANAGEMENT INFORMATION SUPPORT OF REGIONAL INNOVATIONS
}

\author{
A.V. Masloboev ${ }^{\mathrm{a}, \mathrm{b}}$, M. Langhans
}

${ }^{\text {a }}$ Institute for Informatics and Mathematical Modeling of the Federal Research Center "Kola Science Center of Russian Academy of Sciences", Apatity, 184209, Russian Federation

${ }^{\mathrm{b}}$ Murmansk Arctic State University, Apatity, 184209, Russian Federation

${ }^{\mathbf{c}}$ Ludwig-Maximilians-University Munich (LMU), Munich, 80539, Germany

Corresponding author: masloboev@iimm.ru

Article info

Received 17.04.18, accepted 17.05 .18

doi: 10.17586/2226-1494-2018-18-4-630-638

Article in English

For citation: Masloboev A.V., Langhans M. A multi-agent system for management information support of regional innovations. Scientific and Technical Journal of Information Technologies, Mechanics and Optics, 2018, vol. 18, no. 4, pp. 630-638 (in English). doi: 10.17586/2226-14942018-18-4-630-638

\section{Abstract}

This paper presents development experience of architecture, principles of functioning, software engineering and modeling of multi-agent system for information support of regional business processes. The main purpose of the system is integration of distributed heterogeneous information resources and web-services devoted to innovations in the Internet. The system provides an automated search of potential business partners, an interactive innovation chains construction and selection thae most efficient of them. The necessity of system dynamics modeling methodology using in development of business processes support systems is discussed. Agent-based technologies are examined. Special attention is given to development of virtual business environment conceptual model. Our conceptual model is used as a basis for the system structure, algorithms, functionality and relationships between its main architectural components representation. Specifically, we show how to use the conceptual modeling methodology, system dynamics and multi-agent system technology in developing a multi-agent system for integration of distributed heterogeneous information resources and services devoted to innovations.

Keywords

multi-agent system, information support, management, innovation process, conceptual modeling

Acknowledgements

The work is sponsored by the Federal Agency of Scientific Organizations and the Russian Foundation for Basic Research under grant No. 18-07-00167-a.

\section{УДК 004.89, 004.94 \\ МУЛЬТИАГЕНТНАЯ СИСТЕМА ИНФОРМАЦИОННОЙ ПОДДЕРЖКИ УПРАВЛЕНИЯ РЕГИОНАЛЬНЫМ ИННОВАЦИОННЫМ РАЗВИТИЕМ}

\section{А.В. Маслобоев ${ }^{a, b}$, М. Лангханс}

${ }^{a}$ Институт информатики и математического моделирования Федерального исследовательского центра «Кольский научный центр Российской академии наук», Апатиты, 184209, Российская Федерация

b Мурманский арктический государственный университет, Апатиты, 184209, Российская Федерация

c Мюнхенский университет им. Людвига Максимилиана, Мюнхен, 80539, Германия

Адрес для переписки: masloboev@iimm.ru

Информация о статье

Поступила в редакцию 17.04 .18 , принята к печати 17.05 .18

doi: 10.17586/2226-1494-2018-18-4-630-638

Язык статьи - английский

Ссылка для цитирования: Маслобоев А.В., Лангханс М. Мультиагентная система информационной поддержки управления региональным инновационным развитием // Научно-технический вестник информационных технологий, механики и оптики. 2018. T. 18. № 4. C. 630-638. doi: 10.17586/2226-1494-2018-18-4-630-638

Аннотация

В работе представлены результаты исследований в области разработки мультиагентных систем информационной поддержки управления инновационными процессами в регионе. Рассматриваются особенности построения архитектуры, принципы функционирования, элементы программной реализации и моделирования данного типа систем. Целью создания системы является интеграция распределенных разнородных информационных ресурсов и 
веб-сервисов по инновационной деятельности в сети Интернет. Система предназначена для обеспечения автоматизированного поиска потенциальных бизнес-партнеров для реализации инновационных проектов, а также для автоматизированного формирования инновационных структур и оценки их эффективности. Дано обоснование необходимости применения метода системной динамики при моделировании и разработке систем поддержки управления инновационными бизнес-процессами. Исследованы возможности построения и реализации таких систем на базе мультиагентных технологий. Отдельное внимание в работе уделено разработке концептуальной модели виртуальной бизнес-среды развития инноваций. Концептуальная модель является формальной основой для автоматизации синтеза структуры системы и алгоритмов ее функционирования, а также определяет взаимосвязи между базовыми функциональными элементами системы. Новизна и практическая значимость работы заключается в развитии теории и практики комбинированного использования методов концептуального, системно-динамического и мультиагентного моделирования для разработки интеллектуальных систем поддержки управления инновационным развитием региональной экономики.

\section{Ключевые слова}

мультиагентная система, информационная поддержка, управление, инновационный процесс, концептуальное моделирование

\section{Благодарности}

Работа выполнена при поддержке Федерального агентства научных организаций и Российского фонда фундаментальных исследований (проект № 18-07-00167-a).

\section{Introduction}

In the new millennium just countries susceptible to innovations will stand up to competitive struggle on the global wares and services market. Therefore, transition to innovation economics is very relevant for all of the countries which have a great tendency in the field of raw materials. Thus, for today it is conventional and quite obvious fact that innovations are critical element of modern business system development which provides their competitiveness. Business process participants are geographically distributed. Modern economic and scientific relations not only overcome wide distances, but very often "remove" any intergovernmental frontier. Growing up day after day number of innovation activity fellows and their geographic distribution condition on the fact that just lesser part of potentially efficient innovation projects are practically realized. Innovation markets peculiarities put forward new requirements for management problem-solving quality and efficiency which influence on socio-economic systems development process. These claims settlement is not possible without adequate information support of business processes within the systems. We can propose many other arguments to validity of proposals listed above.

Information support of innovations and business processes management are very actual problems. We see two significant interconnected aspects of these problems. There are necessity of potential business partners automation seeking and necessity of problem-oriented innovation chains, which are aimed to specific innovation projects realization, automation construction.

At the present time a great number of information resources are created devoted to innovations. At the same time the most part of them is implemented as special Web-resources, specifically Internet-portals which have the approximate structure of business suggestions representation, but which are not interrelated to each other in the general case. For enhancement of business processes information support efficiency we see a relevant solution which consists in flexible and user-transparent sharing of information about existing innovation suggestions stored in the heterogeneous business-oriented Internet-portals databases. Thereupon, we see the urgency of innovations information support systems development and propose such system prototype [1]. The necessity of the system for integration of distributed information resources devoted to innovations [2] creation consists in many problems of existing scientific, industrial and commercial organizations Internet-pages access networked systems and databases, which do not provide a due level of information relations interactivity and which are prevented from analytical, consultative and adjusting functions.

\section{Problem statement}

In this section we give some remarks to the terminology used in this paper. The term "innovation" is discussed in different ways [3]. In this paper we consider innovations as a business process of an innovation product realization. Innovation structure is a group of innovation subjects (scientists, developers, producers, investors, etc.) who are engaged in innovation project or final product realization. The business environment which constitutes a set of innovation subjects, resources and structures and where they interact, is considered as a innovation field, which is the part of real world. In some ways we can define the innovation field as innovation services market or innovation infrastructure. We define the same concept for computer networks - Virtual Business Environment. It is the area of the Internet where program agents of innovation subjects interact with each other. The terminology described above will be used in the following sections of this paper.

Information support of innovations is a difficult and very dynamic multivariate task. In such frameworks it is not possible to rely on full management problem-solving process automation. However, this process can be substantially supported by availability of adequate to the current task information collections, formalistic methods and innovation processes simulation modeling computer systems [4], which in complex constitute 
innovation activity information support system.

Complexity and dynamics of such type of tasks cause to the necessity of large information volumes for securing of which we need methods, technologies and tools of existing geographically distributed information resources maximum integration. Task dynamics advances specific requirements to functional features of these technologies - realization of rapid and minimum cost-is-no-object reconfiguration and providing information systems adaptation created with their help. Thus, we can formulate the following requirements to innovations information support system features spectrum:

- flexible recustomizable integration of distributed information resources;

- unitized interface for heterogeneous data sources securing;

- seeking for data sources on basis of their content;

- appropriate access to infobases;

- availability of socio-economic systems reaction modeling methods and tools on external and internal changes.

In our opinion, for today great attention must be paid to the utmost to the following technologies which provide the requirements listed above. There are heterogeneous data-processing resources integration technologies based on Grid systems (Grid technologies) [5], P2P-systems technology [6] and multi-agent technologies [7] which provide distributed data-processing tasks solving.

These technologies provide unitized access to geographically distributed heterogeneous data sources composing necessary infobase for current situation analysis for the purpose of management problem-solving and formation.

\section{Related work}

One of the possible decisions to eliminate the drawbacks of the existing (not agent-oriented) business process management systems is to involve agent technologies in coordination of business processes.

An agent based business process support and management system (BPSMS) is a set of software components that meet the criteria to be considered as agents and are involved in managing the flow of work through a business process [8]. The idea of the agent-based BP management systems is to split business process into parts and trust the control over such part to individual software agents (Fig. 1).

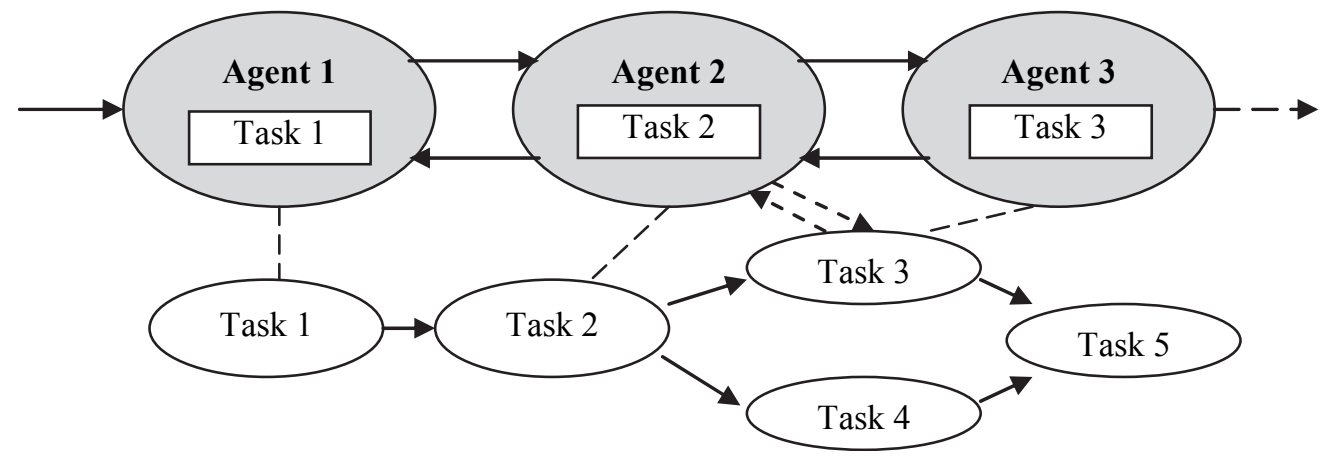

Figure 1. Agent-oriented business process

An agent-based approach allows splitting business process into groups in order to commit the coordination of this process groups to autonomous or semiautonomous software agent. Business logic, explicitly defined to the agent by some set of business roles, is intended to show agent's task and resource dependencies from the other business process participants, which usually although are agents. Agents use business logic to plan their activities in order to achieve goal of the concrete process participant. Communication protocols are implemented in order to enable the agent to synchronize their actions.

Conceptual model of the agent-based BPMS is shown in Fig. 2. Knowledge about the business process logic is distributed among participants of the process. Each agent acts according to his user goal, provides actual information about participant's current tasks and deadlines. Intelligent agents should be possible to plan their actions, make searches for achievements of alternative goal solution parts, explain own actions to the user and make advice.

$[9,10]:$

Here the authors sum up the main advantages of an agent-based business process management usage

- the use of goal oriented, communicating autonomous agents, which although concern about business logic, allow multiple solution paths to the business process goal to be achieved;

- agent-based technologies allow greater flexibility and dynamism in the business process management system. Decoupling components of the system allow them to be swapped out, replaced, or even added to the system without impacting the other parts; 
- allows decentralized ownership of the tasks, information and resources involved in the business process;

- agent-based systems provide access to the system, even if the system is physically distributed. They allow building highly decentralized, distributed systems, which corresponds to the real world situation, when the business processes in organizations are physically distributed (this distribution may be across one site, across a country, or even across continents);

- the use of autonomous agents provides high degree of natural concurrency, when many interrelated tasks are running at any given point of the business process.

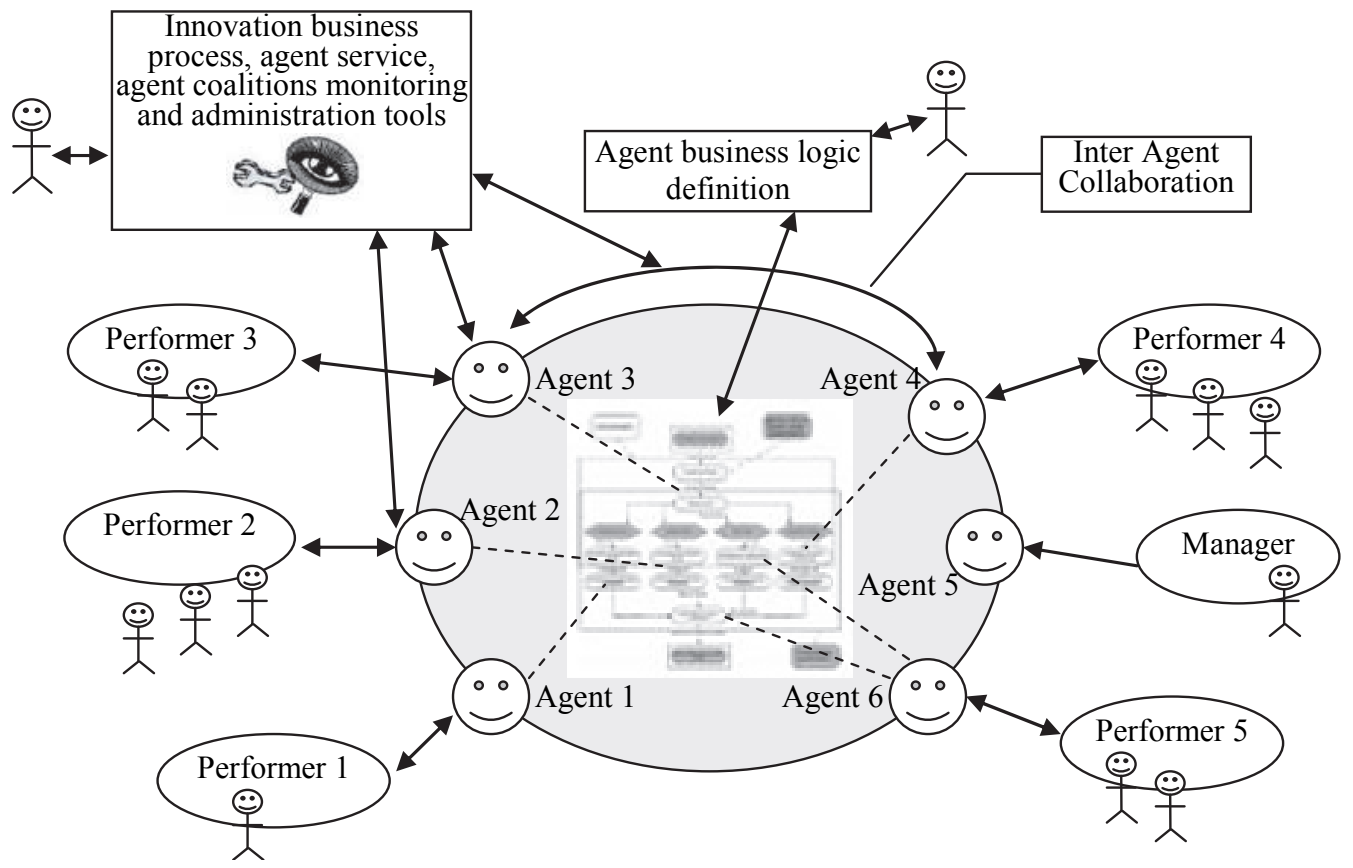

Figure 2. Conceptual model of agent-based business process management system

As mentioned in [11] the very nature of the agent paradigm leads to a number of problems, common to all agent-based applications:

- the agent-based systems have no overall system controller. It means that an agent-based solution is not the best choice for managing business processes with a lot of global constraints to be maintained. Agentbased solution is not appropriate for domains in which global constraints have to be maintained, in domains where a real-time response must be guaranteed, or in domains in which deadlocks must be avoided;

- agent-based systems have no global perspective. An agent's actions are, by definition, determined by that agent's local state. However, since in almost any realistic agent system, complete global knowledge is not a possibility, this may mean that agents make globally sub-optimal decisions. This is one of the main issues that the agent-based business process systems managers should take care of;

- users of the agent-based system usually face with trust and delegation problem. For individuals to be comfortable with the idea of delegating tasks to agents, they must first trust them. Users have to gain confidence in the agents that work on their behalf, and this process can take time.

Agent based workflow systems have been developed by a number of teams, each offering their own particular enhancements and features. The Advanced Decision Environment for Process Tasks (ADEPT) [10] is one of the first agent based workflow systems that was developed at British Telecom for its real business process. The ADEPT system consists of multiple software agents which negotiate concurrently with each other in order to reach agreement on how resources are to be assigned to support a business process. The agents take full responsibility for business process provisioning, execution and compensation, with each agent managing and controlling a given task or a set of tasks. Other systems, such as DartFlow BPMS [12], TRP (Technology Reinvestment Project) project support environment [13], RSA BPMS [14], etc. introduce their own agent-based approaches for BPM.

\section{Virtual Business Environment Conceptual Model}

Virtual Business Environment Conceptual Model (VBE CM) has a hierarchical structure and consists of the following component set: model objects (innovation subjects - innovation process participants) $-S$, innovation subjects agents $-A$, which simulate the innovation subjects activity in the VBE and form problem- 
oriented innovation structures $-B S$ of distributed innovation components, business-processes $-P$, $R=\{B I, B P L\}-$ innovation resources, which are devoted to business ideas (innovation suggestions) $-B I$ and business plans (investment suggestions) $-B P L$. Business suggestions which appear in our system are divided in two classes: generalized and itemized business ideas. Such business ideas description sharing provides the possibility to form business plots in the VBE. These business plots consolidate the innovation processes participants, which have closed interests or goals and a high communication probability. In turn, this conduces to increase the agent interaction efficiency and network load reduction.

VBE conceptual model objects, which represent the innovation subjects, form a hierarchy that makes it possible to take into consideration the organizational subordination of innovation subjects in the innovation structures formation process.

Here our conceptual model scheme is represented: $E_{B D C}=\{S, P, I, A, R, A t r\}$.

On the model objects sets we define the following relations which describe the VBE infrastructure:

$I=\{S A, S P, S B S, S B I, S B P L$, In, Out,$H\}$,

where $B I \subseteq B I \times A$ - correspondence relation between an agent and a business idea which it promotes; $S P \subseteq S \times P$ - participation relation between innovation subject and business process in which he takes part: $S B S \subseteq S \times B S$ - affiliation relation between subject and innovation structure; $S B I \subseteq S \times B I$ - affiliation relation between business idea and innovation subject; $S B P L^{\text {ind }} \subseteq S \times B P L^{\text {ind }}$ - affiliation relation between business plan and innovation subject; $B S B P L^{g e n} \subseteq B S \times B P L^{\text {gen }}-$ affiliation relation between generalized business plan and innovation structure; $B S P \subseteq B S \times P$ - participation relation between innovation structure and business process; $I n \subseteq P \times B(R)$ - relation "input process data - process" and $O u t \subseteq P \times B(R)$ - relation "process - output process data"; $H=\bigcup_{\alpha=1}^{N_{l}-1} H^{\alpha}, H^{\alpha} \subseteq S_{\alpha-1} \times B^{\prime}\left(S_{\alpha}\right)-$ hierarchy relation between model objects (where $S_{\alpha}$ - a set of objects on the level $\alpha, B^{\prime}\left(S_{\alpha}\right)$ - separation of set $\left.S_{\alpha}\right)$.

Agents $A=\left\{S, B I, O R G^{A}, C^{A}\right\}$ represent relevant goals and interests of their owners (innovation subjects) in the VBE. Agent descriptions are given in accordance to our terminology. An agent promote the business suggestions in VBE and its description includes a set of innovation suggestions ( $B I)$, a set of basic organizational structures $\left(O R G^{A}\right)$, which correspond to specific agent functions (agent roles), and agent internal structure $\left(C^{A}\right)$ which describes the functional unit of the agent.

In our conceptual model terminology a business structure $B S=\left\{A, B I^{G E N}, B P L^{C O M}\right\}$ constitutes coherent fragments which include satisfied defined conditions model objects. These agent groups (coalitions) are unified by one common goal or goals to realize the appropriative business ideas. A set of generalized ideas $B I^{G E N}$ which consolidate model objects into business structures and a set of generalized business plans $B P L^{C O M}$ on the basis of which the business ideas are realized, are defined for business structures. Business structures are formed on the basis of relationships between conceptual model components analysis of the developed conceptual model functions as an ontology of innovations.

A business idea $B I=\{K D, A D\}$ is described as a set of key parameters $K D$ and a set of additional parameters $A D$. Business idea description is used in automatic formation of agent coalitions. We give such representation of business ideas to provide information exchange reduction between the agents, which goals essentially differ, to simplify and to activate intra-group agent interactions. The set of parameters includes both stringently typed parameters, which are described in terms of general-system thesaurus, and parameters, which are described with natural language. Agent coalition formation is carried out on the basis of semantic comparison of appropriative business ideas parameters.

A business plan $B P L=\{G P, I P, R P\}$ constitutes a set of the following quantitative parameters: $G P-$ a set of parameters, which describe the information part of innovation project, $I P$ - a set of parameters, which describe the investment part of innovation project and $R P$ - set of parameters, which describe the resort part of innovation project. This $B P L$ description refines the innovation suggestion and gives a proper way to formalize business plan and represent its main attributes: pay-back period, upcoming production release volume, required investment volume, business partners reliability, etc.

Object attributes model in the VBE CM has the following description:

Atr $=\left\{T, N M, T_{h}\right\}$,

where $T=\left\{T_{S}, T_{A}, T_{P}, T_{B I}, T_{B P L}, T_{R}, T_{B S}\right\} ; N M=\left\{N M_{S}, N M_{A}, N M_{P}, N M_{B I}, N M_{B P L}, N M_{R}, N M_{B S}\right\}-$ are the sets of types and names of model objects, agents, processes, resources, business ideas, plans and structures in VBE CM correspondingly; $T_{h}$ - a set of object hierarchy relation types. 
The innovation activity formal representation in our conceptual model provides some significant features for the future investigations, such as automated analysis of knowledge domain structure and properties, and development of innovation structure efficiency evaluation algorithms; formulation of the optimization problems of the most effective variants selection for business projects realization; unified description of agent interaction algorithms and execution environment specifications for innovation processes simulation realization, in terms of our basic conceptual model.

\section{System functioning logic}

New information technologies dynamic development concerned with global network Internet provides innovation activity information support distributed multi-agent systems creation on the basis of agent technologies and Semantic Web Project concepts and principles. The Semantic Web Project [15] main purpose consists in information systems for global network development for autonomous program agent work and interaction that gives the possibility to automatize a lot of tasks solving with the Internet, for example, in the following spheres: e-business, medicine, financial operations, electronic libraries, distance education, etc.

System functioning logic and its functional structure are described using our agent-based VBE conceptual model which constitutes a formal object, relationships between them and attributes description in the form of settheoretical definitions.

System functioning principles reproduce in many respects the ideas laid under Semantic Web concept [16]. But in contrast to this Semantic Web concept where initially it is implied that seeking, registration, update and data processing processes are initiated by user in our developed system such processes initiators, analogous to the same in Semantic Web concept, are agents which are directly representatives of their owner within the system. Thus, innovation subject has just to register his own node (host) in the distributed virtual business environment, configure his agents required options and wait for results of agent activity. All the work related with seeking for business partners and preliminary innovation chains potential efficiency analysis is in the agent competence. During the system functioning agents communicate with ultimate users representing results of their own activity for consideration to them and requesting for qualifying information about innovation supplies declared user in case of structure or innovation field attributes (agent functioning scene) changing or business supplies information insufficiency. At the same time the user can choose how it will be carried out: in interactive mode in the way of question-answer or in automatic mode.

\section{System architecture}

In comparison with existing innovations information support software, our system has an open decentralized hybrid architecture providing organization of more efficient search of potential business partners and innovation structures formation. Thus, designed system architecture provides asynchronous agent communication and interaction character that gives the possibility of their work in the frameworks of heterogeneous and unreliable communications which are extremely relevant regional scale systems. Active nature of developed program agents position multi-agent systems is an efficient feature for distributed data processing (DDP). In one's turn agent autonomy and their cooperation ability enabled us to develop flexible and easily reconfigurable distributed system.

The system components form an entire logical virtual business environment. Each program agent represents some business suggestions of its owner which are registered at one of the existing business-oriented portals in the VBE. The main goal of the agent is to find suitable potential business partners for its owner's business ideas or investment realization. The agent reaches this goal by negotiating and interacting with the other agents.

To decrease the networked data level passed between agents during agent communications, we have developed two technological types of agents: mobile agents which are able to migrate between the network nodes for local search of negotiation partners execution, and local agents, which represent the interests of their owners at the server side (portal), where the appropriative business suggestion is registered. Local agents do not show any initiative to business partners seeking, but they provide communications and negotiations with the other local or mobile agents.

The system provides the following features:

- potential business partners search using semantic analysis of business suggestions attributes description registered at the portals;

- innovation structures formation during inter-agent communications in the VBE;

- translation of the object retrieval requests, which were formulated in general-system terms, to portal local terms, which is the current retrieval object;

- quantitative parameters of formed innovation structures variants estimation and automated selection of the most efficient of them;

- innovation suggestions parameters and appropriate program agents configuration during the user dialog.

System architecture is shown in Fig. 3. The system consists of the following main functional units. 
- Agency. The agency is loaded on the server agent-platform side (portal related with innovations). This agency moreover consists of two main parts which represent local (home) and guest agencies. The first part implements agent generation function and provides program code of local agents execution. The other part provides execution environment for guest agents which have migrated from the other network nodes to the current host.

- Mobile program code which implements mobile agents. Development of mobile agents in the form of mobile program code provides system functional flexibility - to change random implementation of innovation structure parameters estimation algorithms and agent behavior logic on the assumption of interface calls retention. Our mobile agents are developed using Java Language in JADE (Java Agent Development Environment).

- Knowledge domain ontology server which provides unified terminological base for general-system and local retrieval requests during objects and innovation ideas seeking.

- Request translator which provides retrieval requests formation to portal local databases on the basis of incoming request represented in general-system terms. The knowledge domain ontology, which is stored on the distinguished ontology server, is used during the translation.

- Software components which implement internal agent functioning logic and inter-agent communicational protocols.

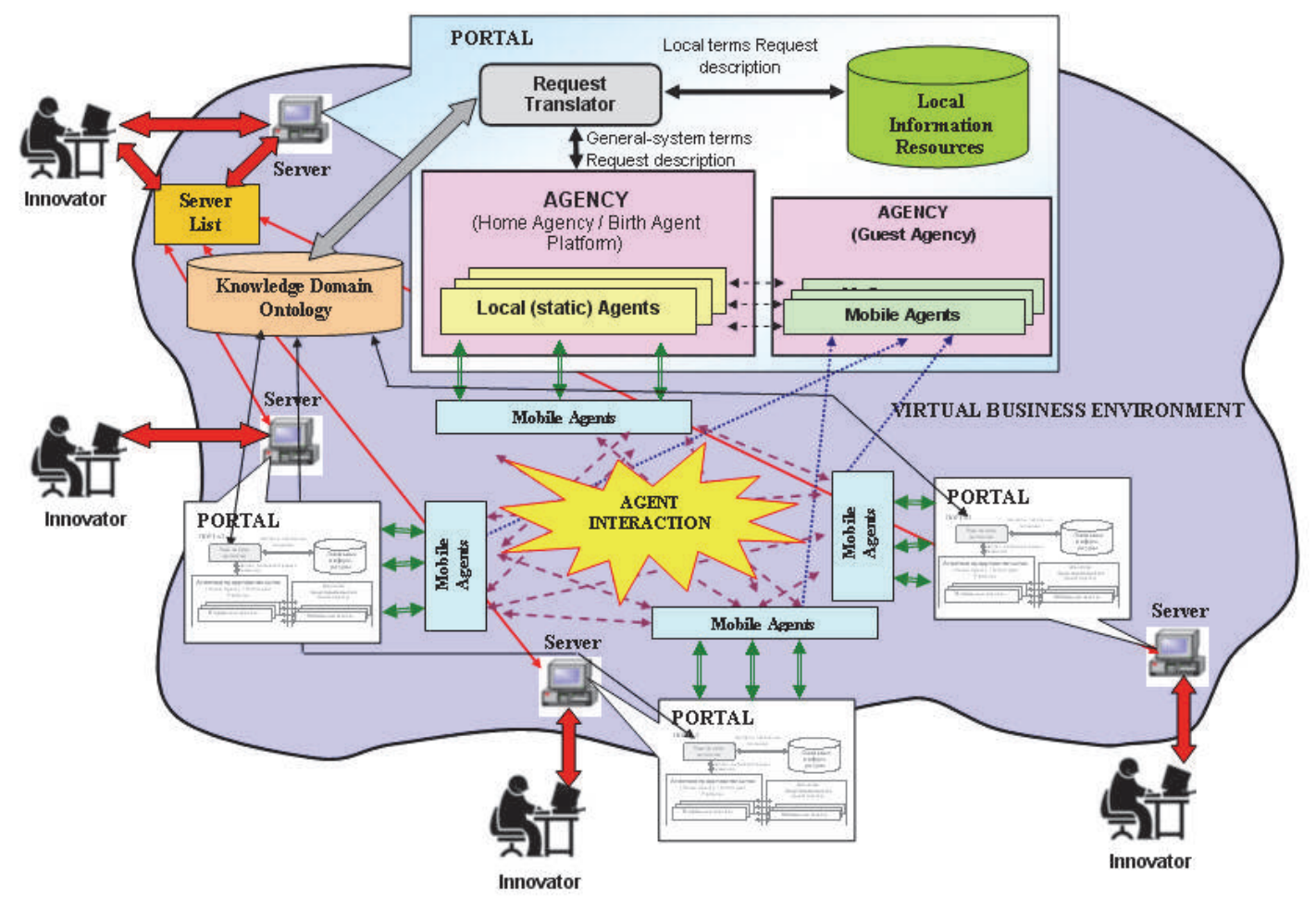

Figure 3. System Architecture

The system represented in this paper gives the possibility to increase the efficiency of innovation processes information support at the expense of features to organize flexible sharing of heterogeneous geographically distributed information resources related with innovations and routine operations automation which are concerned with congenial business partners seeking needed to realize efficient innovation projects and potential innovation structures availability evaluation.

\section{Implementation}

The agent architecture, which describes its functional unit, can be represented as follows: $C^{A}=\langle K, M, P, R, I, C\rangle$, where $K$ - artificial subsystem; $M$ - simulation subsystem; $P$ - analysis and planning subsystem; $R$ - reaction subsystem; $I$ - coordination and interaction subsystem; $C$ - communication subsystem.

Artificial subsystem $(K)$ is implemented using KIF language (Knowledge Interchange Format). Agent knowledge base is based on the knowledge representing production model.

To implement production knowledge base three following modules are used: a database, a production system which is written on the reference language, and interpreter for productions processing. The agent core, specifically memory control subsystem, knowledge bases, etc., are developed using Java language, because it is important to provide agent ability for migration between the system nodes. 
Simulation subsystem $(M)$ provides the local prediction of agent potential activity results. The simulation subsystem constitutes full or simplified model of the agent interaction environment, which is recurrently invoked during the simulation. We have used system dynamic models as the simulation subsystem implementer.

The analysis and action planning subsystem $(P)$ and also reaction subsystem $(R)$ are implemented using traditional languages for agent behavior description. There are operational (action) algebra and behavioral algebra. Communication subsystem $(C)$ and coordination and interaction subsystem $(I)$ are developed using agent communication language (ACL).

To implement actor-based agent models we used algebraic programming system (APS) which is based on APLAN language. This algebraic programming system provides combination of different programming paradigms (procedural, functional, algebraic) during system development process. To describe our distributed agent interaction subsystem we used algebraic-logic operational language AL, which is a part of APS.

We have chosen Java RMI as the technology for our system development. In comparison to CORBA, this technology provides more flexible features to Java-platform-oriented distributed application creation, including the possibility to develop mobile applications.

System agents are developed using Java language which is oriented on asynchronous interaction process realization and remote application execution.

\section{Conclusions}

The information support of innovations problem has a multidimensional character. High dynamics of innovation-oriented regional economics from the one side and inertness of socio-economic system in reaction on innovation management from the other side, improve the role and significance of innovations information support task. For specific claims settlement advanced to corresponding information support systems it is necessary to use modern progressive methods and technologies of distributed information systems development, such as Grid, Peer-to-Peer (P2P), Multi-agent systems (MAS) technologies and some methods of system dynamics.

In this paper we proposed architecture, principles of functioning and development experience of multiagent system for information support of innovations.

This innovation chains construction mechanism is based on applying the agent-oriented approach to nonlinear model of innovation process which we did not describe in this paper. Knowledge and data integration subsystem incoming into business-portal is used for its realization with the help of which integration of geographically distributed heterogeneous information resources related with innovations and semantic search within them are provided.

Our system is developed on the basis of multi-agent system technology that makes it possible to carry out active seeking of potential efficient innovation chains which consist of geographically distributed elements.

The system is functioning on the basis of interaction scenarios of business process participants and is oriented to be used in large computer networks with wide service diversity.

Developed system in its full functionality (communications, seeking, registration, updates and information processing according to description given above) is intended for information support of innovation processes and can be used by virtual organizations participants which use the Internet as data source. The system allows improving the efficiency of inter-group communicative processes in order to facilitate interactions with network data sources and to form innovation chains on the basis of receiving information and integration of distributed heterogeneous information resources related with innovations in the WWW.

\section{Литература}

1. Masloboev A., Putilov V. Information Dimension of Regional Security in the Arctic. Apatity, Kola Science Center Publishing, 2016. $222 \mathrm{p}$

2. Vorbach S., Perl E. Software based support for innovation processes // Proceedings of I-KNOW '05. Graz, Austria, 2005. P. 220-227.

3. OSLO MANUAL. The Measurement of Scientific and Technological Activities: Proposed Guidelines for Collecting and Interpreting Technological Innovation Data. European Commission, Eurostat [Электронный pecypc]. Режим доступа: www.oecd.org/dataoecd/35/61/2367580.pdf (дата обращения 19.05.2018),

4. Milling P.M. Modeling innovation processes for decision support and management simulation // System Dynamics Review. 1996. V. 12. N 3. P. 211-234.

5. Foster G., Kesselman C., Nick J., Tuecke S. Grid services architecture for distributed systems integration // Extensible Systems. 2003. N 1. P. 20-26.

6. Smithson A., Moreau L. Engineering an agent-based peer-topeer resource discovery system // Lecture Notes in Computer

\section{References}

1. Masloboev A., Putilov V. Information Dimension of Regional Security in the Arctic. Apatity, Kola Science Center Publishing, 2016, 222 p.

2. Vorbach S., Perl E. Software based support for innovation processes. Proceedings of I-KNOW' '05. Graz, Austria, 2005 , pp. 220-227.

3. OSLO MANUAL. The Measurement of Scientific and Technological Activities: Proposed Guidelines for Collecting and Interpreting Technological Innovation Data. European Commission, Eurostat. Available at: www.oecd.org/dataoecd/35/61/2367580.pdf (accessed 19.05.2018)

4. Milling P.M. Modeling innovation processes for decision support and management simulation. System Dynamics Review, 1996, vol. 12, no. 3, pp. 211-234.

5. Foster G., Kesselman C., Nick J., Tuecke S. Grid services architecture for distributed systems integration. Extensible Systems, 2003, no. 1, pp. 20-26.

6. Smithson A., Moreau L. Engineering an agent-based peer-topeer resource discovery system. Lecture Notes in Computer 
Science. 2003. V. 2530. P. 69-80. doi: 10.1007/3-540-4507427

7. Hendler J. Agents and the semantic web // IEEE Intelligent Systems. 2001. V. 16. N 2. P. 30-37. doi: 10.1109/5254.920597

8. Pang G. Implementation of an Agent-Based Business Process. Technical Report, University of Zurich, 2000.

9. Bolcer G.A., Taylor N.R. Advanced workflow management technologies // Software Process Improvement and Practice. 1998. V. 4. N 3. P. $125-171$.

10. Jenning N.R., Faratin P., Johnson M.J. et al. Agent-based business process management // International Journal of Cooperative Information Systems. 1996. V. 5. N 2-3. P. $105-$ 130.

11. Jennings N.R., Wooldridge M. Application of intelligent agents / In: Agent Technology. Springer, 1998. P. 3-98. doi: 10.1007/978-3-662-03678-5_1

12. Cai T., Gloor P.A., Nog S. DartFlow: A Workflow Management System on the Web Using Transportable Agents. Technical Report PCS-TR96-186. Dartmouth College, 1996.

13. Chang J.W., Scott C.T. Agent-based workflow: TRP support environment (TSE) // Computer Networks and ISDN Systems. 1996. V. 28. P. 1501-1511. doi: 10.1016/0169-7552(96)00068-2

14. Hawryszkiewycz I., Debenham J. A workflow system based on agents // Proc. $9^{\text {th }}$ Int. Conf. Database and Expert Systems Applications, DEXA'98. Vienna, Austria, 1998. P. 135-144. doi: $10.1007 / \mathrm{BFb} 0054475$

15. Terziyan V., Kononenko O. Semantic web enabled web services: state-of-art and industrial challenges // Lecture Notes in Computer Science. 2003. V. 2853. P. 183-197.

16. Mcllraith S.A., Son T.C., Zeng H. Semantic web services // IEEE Intelligent Systems. 2001. V. 16. N 2. P. 46-53. doi: $10.1109 / 5254.920599$

\section{Авторы}

Маслобоев Андрей Владимирович - доктор технических наук, доцент, ведущий научный сотрудник, Институт информатики и математического моделирования Федерального исследовательского центра «Кольский научный центр Российской академии наук», Апатиты, 184209, Российская Федерация; профессор, Мурманский арктический государственный университет, Апатиты, 184209, Российская Федерация, ORCID ID: 0000-0002-1231-9225, masloboev@iimm.ru

Мария Лангханс - магистр естественных наук, аспирант, Мюнхенский университет им. Людвига Максимилиана, Мюнхен, 80539, Германия, ORCID ID: 0000-0002-7462-206X, marel-ka@yandex.ru
Science, 2003, vol. 2530, pp. 69-80. doi: 10.1007/3-54045074-2_7

7. Hendler J. Agents and the semantic web. IEEE Intelligent Systems, 2001, vol. 16, no. 2, pp. 30-37. doi: 10.1109/5254.920597

8. Pang G. Implementation of an Agent-Based Business Process. Technical Report, University of Zurich, 2000.

9. Bolcer G.A., Taylor N.R. Advanced workflow management technologies. Software Process Improvement and Practice, 1998, vol. 4, no. 3, pp. 125-171.

10. Jenning N.R., Faratin P., Johnson M.J. et al. Agent-based business process management. International Journal of Cooperative Information Systems, 1996, vol. 5, no. 2-3, pp. 105-130.

11. Jennings N.R., Wooldridge M. Application of intelligent agents. In: Agent Technology. Springer, 1998, pp. 3-98. doi: 10.1007/978-3-662-03678-5_1

12. Cai T., Gloor P.A., Nog S. DartFlow: A Workflow Management System on the Web Using Transportable Agents. Technical Report PCS-TR96-186. Dartmouth College, 1996.

13. Chang J.W., Scott C.T. Agent-based workflow: TRP support environment (TSE). Computer Networks and ISDN Systems, 1996, vol. 28, pp. 1501-1511. doi: 10.1016/01697552(96)00068-2

14. Hawryszkiewycz I., Debenham J. A workflow system based on agents. Proc. $9^{\text {th }}$ Int. Conf. Database and Expert Systems Applications, DEXA'98. Vienna, Austria, 1998, pp. 135-144. doi: $10.1007 / \mathrm{BFb} 0054475$

15. Terziyan V., Kononenko O. Semantic web enabled web services: state-of-art and industrial challenges. Lecture Notes in Computer Science, 2003, vol. 2853, pp. 183-197.

16. McIlraith S.A., Son T.C., Zeng H. Semantic web services. IEEE Intelligent Systems, 2001, vol. 16, no. 2, pp. 46-53. doi: $10.1109 / 5254.920599$

\section{Authors}

Andrey V. Masloboev - D.Sc., Associate Professor, leading scientific researcher, Institute for Informatics and Mathematical Modeling of the Federal Research Center "Kola Science Center of Russian Academy of Sciences", Apatity, 184209, Russian Federation; Professor, Murmansk Arctic State University, Apatity, 184209, Russian Federation, ORCID ID: 0000-0002-1231-9225, masloboev@iimm.ru

Maria Langhans - Master of Science, postgraduate, LudwigMaximilians-University Munich (LMU), Munich, 80539, Germany, ORCID ID: 0000-0002-7462-206X, marelka@yandex.ru 